\title{
Methodology Adjustments for Organic Acid Tolerance Studies in oat under Hydroponic Systems
}

\author{
Mauricio Marini Kopp ${ }^{1 *}$, Viviane Kopp da Luz $^{2}$, Velci Queiróz de Souza ${ }^{3}$, Jefferson Luis \\ Meirelles Coimbra ${ }^{4}$, Rogério Oliveira de Sousa $^{5}$, Fernando Irajá Félix de Carvalho ${ }^{6}$ and \\ Antonio Costa de Oliveira ${ }^{6}$ \\ ${ }^{1}$ Laboratório de Biotecnologia e Fisiologia Vegetal; Embrapa Gado de Leite; 36038-330; Juiz de Fora - MG - \\ Brasil. ${ }^{2}$ Ciência e Tecnologia de Sementes; Faculdade de Agronomia Eliseu Maciel; Universidade Federal de \\ Pelotas; Pelotas - RS - Brasil. ${ }^{3}$ Departamento de Agronomia; Universidade Federal de Santa Maria; 98400-000; \\ Frederico Westphalen - RS - Brasil. ${ }^{4}$ Centro Agroveterinário; Universidade do Estado de Santa Catarina; C.P.: \\ 281; 88520-000; Lages - SC - Brasil. ${ }^{5}$ Departamento de Solos; Universidade Federal de Pelotas; Pelotas - RS - \\ Brasil. ${ }^{6}$ Departamento de Fitotecnia; Faculdade de Agronomia Eliseu Maciel; Universidade Federal de Pelotas; \\ Capão do Leão - RS - Brasil
}

\begin{abstract}
The occurrence of anaerobic conditions in hydromorphic soils favors the development of anaerobic microorganisms that produce phytotoxic substances representing primarily by organic acids. The selection of promising oat (Avena sativa L.) genotypes for use in those situations requires field evaluations that can be cumbersome, making hydroponics a viable alternative. The objective of this work was to adjust a methodology to use in studies of tolerance to organic acids in oat under hydroponic systems. For such goal, the best germination system was determined in order to reduce the seedling initial establishment effects under hydroponics, the ideal concentration for screening genotypes and the best variable for stress evaluation. It was found that the most efficient germination system was "pleated germination paper" with small and husked seeds. The best concentration for studying organic acid tolerance ranged from 2.3 to $6.2 \mathrm{mM}$ and the most suitable variable for the evaluation was root length.
\end{abstract}

Key words: Phytotoxicity, levels, abiotic stress, genetic breeding

\section{INTRODUCTION}

Oat is an important alternative for crop rotation, due to its soil recovering properties, having a fundamental role in no-tillage sowing systems. Thus, oat is an excellent crop for increasing the agricultural diversity in monoculture regions, such as the southern half of the Rio Grande do Sul state, where irrigated rice is frequently succeeded by native pastures (Porto, 1997).

The southern region of Brazil represents an area of 6.8 million ha of lowland soils, representing $20 \%$ of the total area of Rio Grande do Sul state (Pinto et al., 2004). The majority of cultivated species has its growth and yield decreased in this soils due to a low natural drainage which promotes an anaerobic environment, favoring the formation of toxic substances (Camargo et al., 2001). Since the soil is frequently under water, the $\mathrm{O}_{2}$ supply is about 10,000 times slower than in dry soils (Ponnamperuma, 1972). After the consumption of the $\mathrm{O}_{2}$ present in the soil, the aerobic microorganisms stop growing and the anaerobic microorganisms, predominantly bacteria, proliferate at the expense of energy present in the organic matter. During the anaerobic

\footnotetext{
*Author for correspondence: kopp@cnpgl.embrapa.br
} 
decomposition, intermediate products are formed, resulting primarily from fermentation, among them the short chain aliphatic organic acids (acetic, propionic and butyric), which occur in the concentration range from 0.1 to $14 \mathrm{mM}$ (Sousa, 2001) and generally at 6:3:1 ratio, respectively (Bohnen et al., 2005). These acids reach a maximum value at few days after flooding, which can lead to plant toxicity (Sousa and Bortolon, 2002).

With the introduction of no-tillage systems, in which plant residues are maintained on the soil surface, there is a higher accumulation of short chain organic acids, primarily in areas of low drainage, which can limit the growth and yield of crops being cultivated in these areas. The toxicity by organic acids is detected, at initial developing stages, by lower germination, shorter root system, lower plant weight and height (Sousa and Bortolon, 2002). In cases of more severe toxicity, damage to plant growth may be reflected in other stages, occurring lower tiller number, nutrient absorption and grain yield (Camargo et al., 2001).

Concentrations of $5 \mathrm{mM}$ acetic, butyric and propionic acid reduced rice root growth in 52\%, $75 \%$ and $92 \%$, respectively (Bortolon et al. 2002). However, the combined acid effects were not additive, but interactive, increasing their phytotoxicity (Camargo et al., 2001). Thus, an adequate way of identifying genetic variability for the character is the evaluation of genotype performance under the joint action of acids, because it reflects the real field conditions to which the crop is subject.

The identification and characterization of genetic variability is a very important step for the plant breeder. Techniques of genotype evaluation in controlled environments with the supply of nutritive solutions have been widely used for genotype screening under different stresses (Duncan and Baligar, 1990). While the evaluation of genotypes in artificial environments does not take into account the real environmental selection pressures (Duncan and Baligar, 1990), the selection in field assays groups a large number of uncontrolled variables, such as differential tolerances to environmental, biotic or nutritional stresses (Wright, 1989). Despite these discrepancies, significant correlations between the parameters measured in field tests and artificial environments, with soil or nutrient solution have been reported in many grasses (Bilinski and Foy, 1987). Thus, an efficient way of evaluating genotypes for tolerance to the presence of organic acids in culture media can be accomplished by using hydroponics under the controlled conditions. Since rice is the primary crop for lowland soils, efficient methodologies for evaluating the toxicity are described in the literature (Rao and Mikkelsen, 1977a,b; Camargo et al., 1993; Armstrong and Armstrong, 2001; Sousa and Bortolon, 2002). Since oat is still a minor crop in lowland areas, there have not been many studies focusing the evaluation of its response to excess organic acids, being a prior necessity the adjustment of a protocol for use in hydroponic systems aiming to identify the tolerant genotypes. The main difficulties faced by the oat tolerance studies in hydroponics are related to a variable vigor in seed germination and the lack of biological knowledge regarding organic acid toxic levels. The objective of this work was to develop a protocol to evaluate and identify the variability in oat genotypes for the organic acid tolerance under hydroponic systems.

\section{MATERIAL AND METHODS}

Two experiments were performed, in which the first was characterized by establishing an adequate germination system and the second by determining the doses and response variables more indicated for the study of tolerance to organic acids in oats.

Since the oat seed presents a highly disuniform germination as a function of the environment to which it is subjected (Floss, 1992), the first step in establishing a protocol is to determine a germination system that allows a higher uniformity among the individuals in order to avoid the evaluation errors due to the initial conditions besides a high germination index. Eight different types of germination tests were evaluated for the oat cultivar UFRGS 14 . This cultivar was chosen because it has been used as standard cultivar in many studies, also serving as a parent for a gamma-ray mutant collection. The treatments used were: T1- large seeds with husk in folded germination paper (Cruz, 2001); T2- large husked seeds in folded germination paper; T3- large husked seeds on germination paper; T4- large seeds with husk on germination paper; T5- small husked seeds on germination paper; T6- small seeds with husk on germination paper; T7- small seeds with husk in folded germination paper; and T8- small husked seeds in folded germination paper. The germination system described by Cruz 
(2001) was formed by a germination paper folded in the shape of an 'accordion' which enabled a better water distribution around the seeds. The germination was conducted under $100 \%$ relative humidity in germination chamber at $25^{\circ} \mathrm{C}$ for $72 \mathrm{~h}$. The experiment was designed in random blocks with three replications, with plots containing 500 seeds. The variables analyzed were: germination percentage (\%GE) and percentage of seedlings with emerged shoots $(\% \mathrm{ES})$ in order to determine the most efficient germination system. Another two variables were evaluated: initial root length (IRL) and initial shoot length (ISL). The data relative to $\% \mathrm{GE}$ and $\% \mathrm{ES}$ were evaluated through the generalized linear model procedure (GLM) in order to consider the most appropriate variable distribution (in \%) (Nelder and Wedderburn, 1972) and the estimates of effects were compared through the t test at 5\% error probability, where the treatments that presented higher effects for these variables were the ones that presented higher seed set. For the IRL and ISL, the frequency distributions were obtained for each treatment (Coimbra et al., 2004) and the treatment that presented a higher frequency of observations around the average, was the treatment that enabled the higher germination uniformity.

To verify the concentration range and the most appropriate response variable for the organic acid tolerance in oat, another experiment was developed with the seeds originating from the former experiment, where five treatments were used: T1- $0 \mathrm{mM}$ (control); T2- $1 \mathrm{mM}$; T3- $5 \mathrm{mM}$; T4- $9 \mathrm{mM}$; and T5- $13 \mathrm{mM}$. The ratio for the acids was 6:3:1 for acetic, propionic and butyric acids, respectively. To set up the experimental plots, 150 seedlings with minimum root growth of $5 \mathrm{~mm}$ were selected. The experimental design consisted of 10 seedlings per replication. Pots of $5.5 \mathrm{~L}$ volume, covered with a nylon mesh on the top, were used to give support to the seedling growth.

The nutritive solution consisted of the following: calcium nitrate - $\mathrm{Ca}\left(\mathrm{NO}_{3}\right)_{2} 4 \mathrm{mM}$, magnesium sulfate $-\mathrm{MgSO}_{4} 2 \mathrm{mM}$, potassium nitrate $-\mathrm{KNO}_{3}$ $4 \mathrm{mM}$, ammonium sulfate - $(\mathrm{NH} 4)_{2} \mathrm{SO}_{4} 0,435 \mathrm{mM}$, potassium phosphate $-\mathrm{KH}_{2} \mathrm{PO}_{4} 0,5 \mathrm{mM}$, boric acid - $\mathrm{H}_{3} \mathrm{BO}_{3} 10 \mu \mathrm{M}$, sodium molibdate - $\mathrm{NaMoO}_{4} 0,10$ $\mu \mathrm{M}$, sodium chloride - $\mathrm{NaCl} 30 \mu \mathrm{M}$, zinc sulphate - $\mathrm{ZnSO}_{4} 0,8 \mu \mathrm{M}$, copper sulphate - $\mathrm{CuSO}_{4} 0,3 \mu \mathrm{M}$, manganese sulphate - $\mathrm{MnSO}_{4} 2 \mathrm{mM}$, iron-EDTA $\mathrm{Fe} \mathrm{SO}_{4}+\mathrm{Na} 10 \mu \mathrm{M}$ (Camargo and Oliveira, 1981). The $\mathrm{pH}$ was adjusted to 4.7 with $\mathrm{HCl}(1 \mathrm{~N})$ or $\mathrm{NaOH}(1 \mathrm{~N})$, and monitored daily, because according to Rao and Mikkelsen (1977a), the pH of the nutritive solution in experiments with organic acids was variable and interfered in the acid toxicity. The Seedlings were kept in water bath for 14 days at $25^{\circ} \mathrm{C}$ under artificial light and forced aeration to provide oxygen for the root system.

The analyzed variables were: root length (RL); shoot length (SL); number of roots (NR); length of the first leaf (FLL); first leaf insertion height (FLIH); root dry matter (RDM); and shoot dry matter (SDM). An analysis of variance and a regression adjustment were performed (McCullagh and Nelder, 1989). Also, Pearson's correlation estimates among the studied variables were tested by $t$ test at $5 \%$ error probability. All the procedures for performing the statistical analysis were obtained with the help of the SAS software (Statistical Analysis System, 2002).

\section{RESULTS AND DISCUSSION}

The results from the analysis of variance through the generalized linear models of the first experiment presented significant variations $(p \leq 0.05)$ only for the variable \%ES (data not shown). The variable \%GE did not present differences among the treatments, indicating that all germination methods had the same performance in germination percentage, differing only for the percentage of seeds with shoot emergence. Both the variables were adjusted to a Poisson distribution and were automatically transformed by $\log y$ to obtain the estimators of treatment effects. The results in Table 1 indicated that there was no difference among the estimators of treatment effects for the variable $\% \mathrm{GE}$, as already observed in the analysis of variance.

However, for the variable \%ES, treatment T3 showed superior performance when compared to the others, except T4, which was not significantly different. The percentage of seedlings with apparent shoot was a factor that could contribute for the initial differential development of seedlings subject to treatments. Seedlings with apparent shoots presented higher possibility of metabolizing the toxic substance, since they had a fully developed photosynthetic system, having their establishment facilitated when compared to seedlings without any shoot system, leading to the measurement errors regarding plant tolerance. The remaining treatments presented lower shoot 
emerging indices, but with relatively high values not reflecting in any substantial seed loss at the time of seedling selection for the experimental set up.

Table 1- Comparison of means analyses among the treatments for the characters percentage germination (\%GE, superior diagonal) and percentage of shoot emergence (\%ES, inferior diagonal).

\begin{tabular}{cccccccccc}
\hline Treatments & $\begin{array}{c}\text { Means } \\
\text { (\%ES) }\end{array}$ & T 1 & T 2 & T 3 & T 4 & T 5 & T 6 & T 7 & T 8 \\
\hline Means (\%GE) & & 96.0 & 88.0 & 96.0 & 93.3 & 86.7 & 89.3 & 87.3 & 95.3 \\
T 1 & 76.0 & & $\mathrm{~ns}$ & $\mathrm{~ns}$ & $\mathrm{~ns}$ & $\mathrm{~ns}$ & $\mathrm{~ns}$ & $\mathrm{~ns}$ & $\mathrm{~ns}$ \\
T 2 & 73.3 & $\mathrm{~ns}$ & & $\mathrm{~ns}$ & $\mathrm{~ns}$ & $\mathrm{~ns}$ & $\mathrm{~ns}$ & $\mathrm{~ns}$ & $\mathrm{~ns}$ \\
T 3 & 95.3 & $*$ & $*$ & & $\mathrm{~ns}$ & $\mathrm{~ns}$ & $\mathrm{~ns}$ & $\mathrm{~ns}$ & $\mathrm{~ns}$ \\
T 4 & 82.0 & $\mathrm{~ns}$ & $\mathrm{~ns}$ & $\mathrm{~ns}$ & & $\mathrm{~ns}$ & $\mathrm{~ns}$ & $\mathrm{~ns}$ & $\mathrm{~ns}$ \\
T 5 & 64.0 & $\mathrm{~ns}$ & $\mathrm{~ns}$ & $*$ & $*$ & & $\mathrm{~ns}$ & $\mathrm{~ns}$ & $\mathrm{~ns}$ \\
T 6 & 80.0 & $\mathrm{~ns}$ & $\mathrm{~ns}$ & $*$ & $\mathrm{~ns}$ & $*$ & & $\mathrm{~ns}$ & $\mathrm{~ns}$ \\
T 7 & 71.3 & $\mathrm{~ns}$ & $\mathrm{~ns}$ & $*$ & $\mathrm{~ns}$ & $\mathrm{~ns}$ & $\mathrm{~ns}$ & & $\mathrm{~ns}$ \\
T 8 & 75.3 & $\mathrm{~ns}$ & $\mathrm{~ns}$ & $*$ & $\mathrm{~ns}$ & $\mathrm{~ns}$ & $\mathrm{~ns}$ & $\mathrm{~ns}$ & \\
\hline
\end{tabular}

* Significant by the Chi-square test at $5 \%$ error probability;

${ }^{\text {ns }}$ Non significant by the Chi-square test at $5 \%$ error probability.

${ }^{1} \mathrm{~T} 1$ : large seeds with husk in folded germination paper; T2: large husked seeds in folded germination paper; T3: large husked seeds on germination paper; T4: large seeds with husk on germination paper; T5: small husked seeds on germination paper; T6: small seeds with husk on germination paper; T7: small seeds with husk in folded germination paper; and T8: small husked seeds in folded germination paper.

Fig. 1 presents the frequency distributions for the variables IRL and ISL. It showed that treatment T 8 had a relative class distribution of both variables clustered around the average, i.e., with a higher frequency of individuals in classes relative close to the average itself. In this treatment, the average for root length was $1.96 \mathrm{~cm}$, and $51 \%$ of evaluated individuals presented values in the two classes closest to the average, and for shoot length which had an average of $1.69 \mathrm{~cm}, 52 \%$ of individuals presented values in the two closest classes to the average. Thus, the majority of seedlings presented IRL and ISL values close to the average, indicating that this treatment presented the most uniform seedlings regarding IRL and ISL. Treatment 3 also presented a favorable distribution for the variable ISL, with high frequency of individuals distributed in the class close to the average treatment value (around 50\%). However, a small tendency to elongate the tails for the distribution of the variable IRL was observed, with higher proportion of individuals forming classes above and below the treatment average.

Based on these results, it was concluded that the best condition for evaluating organic acid responses of oat plants could be obtained with a folded paper germination system with small and husked seeds (Treatment 8 ) and an additional 20\% in the number of seeds in order to avoid the variations coming from the lack of shoot emergence in some plants. Thus, an uniform set up of the experiment could be achieved with minimal variation among the observation units.

For the second experiment, the analysis of variance demonstrated significant differences $(\mathrm{p} \leq 0.05)$ among the treatments for all the variables (Fig. 2), except for the variables FLL and FLIH (data not shown). Based on these results, regressions were performed for all the variables, except for the latter two (Fig. 2). 

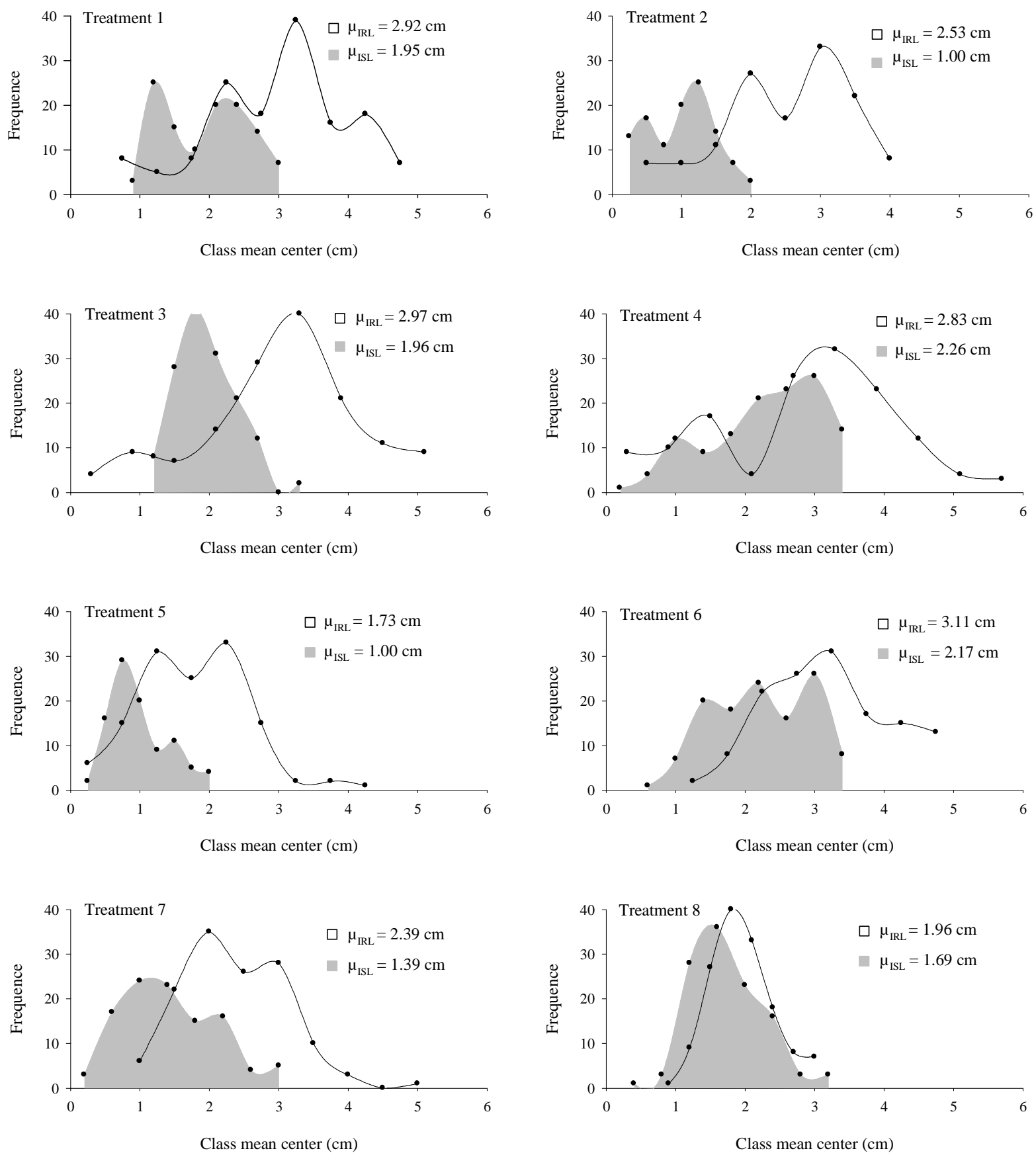

Figure 1 - Mean parameters and graphical representation of variable distribution for initial root length (IRL) and initial shoot length (ISL) subject to eight germination treatments. 

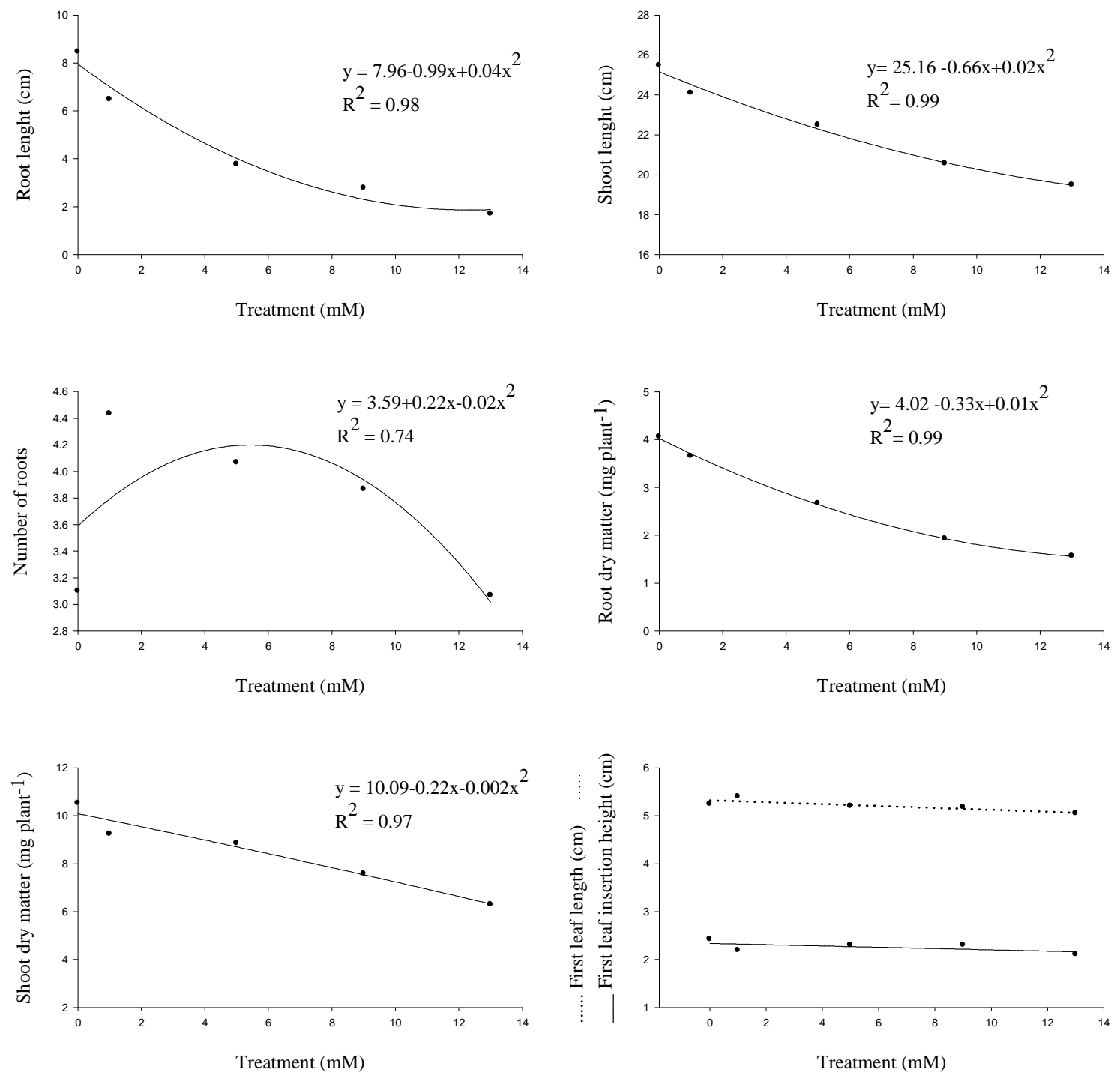

Figure 2 - Graphical representation and respective regression parameters for the variables RL, SL, NR, RDM and SDM subject to five concentration levels of organic acids in hydroponic systems. FLL and FLIH variables are also shown.

In agreement with data for the analysis of variance, Fig. 2 showed that variables FLL and FLIH did not present mean value reduction as a function of the organic acid levels used. For the remaining variables, it was observed that their mean values were reduced as a function of the treatment used. According to the results of the regression adjustments, the variable RL was the one that presented higher response to the doses of organic acids as indicated by the regression coefficient of 0.98 and around $80 \%$ reduction at the highest acid level $(13 \mathrm{mM})$. In rice, maize and soybeans, a high reduction in the root length values was also observed, giving additional supporting evidence that this variable could be indicated for genotype tolerance studies (Harper and Lynch, 1982). The high reductions in this variable were possibly due to its direct contact with the molecules responsible for the phytotoxicity and cell wall degradation, inhibition of respiratory functions and consequently a decrease in cell division (Armstrong and Armstrong, 2001). 
The remainder variables presented average reductions around $23 \%$ for $\mathrm{SL}, 61 \%$ for $\mathrm{RDM}$ and $40 \%$ for SDM. These variables also showed considerable reductions but at smaller degree than RL. The organic acid phytotoxicity is caused by a decrease in respiration and oxidative phosphorylation of the root system, which in consequence also causes reductions in the shoot under stress (Takenaga, 1995). The variable number of roots (NR) presented a differential behavior, i.e., with an initial increase in the dose this variable responded positively increasing its value, while at higher doses its behavior was similar to the other variables with considerable reductions in the mean value. The average reduction for this variable was $30 \%$, but because of its differential behavior, it should not be used for organic acid tolerance studies. These results agreed with previous studies in which rice adventitious roots decreased their growth, promoting calli proliferation at the coleoptile basis, therefore increasing the number of lateral roots (Armstrong and Armstrong, 2001). However, at higher doses, the effect was even more dramatic causing the degradation of these roots leading to a decrease in NR.

The concentration range, which is the most indicated for testing stress tolerance for any abiotic factor, is the one that causes a performance reduction between 30 and $60 \%$ (Jones and Jones, 1992). Thus, the regression estimates for the most responsive variable (RL) showed that these values are between 2.3 and $6.2 \mathrm{mM}$. The use of doses that cause very high reduction on the target variable can lead to a very severe damage, hampering totally the root growth for the evaluated genotypes. This stress level is undesirable, because the seedlings do not differentiate one from another, causing the clustering of all genotypes in one susceptible class. The level of treatment that can be used to classify genotypes according to stress tolerance is the one that distributes the genotypes in a large number of classes, because it discriminates in a broader way the genetic variability among the evaluated accesses, as demonstrated by aluminum stress in rice (Freitas, 2003).

Table 2 shows the simple correlation estimates among the seven studied variables. As expected, due to its differential behavior on the regression analysis, the variable NR did not present a significant correlation with any other variable. Since the most indicated variable for evaluating seedlings was RL, the variables which presented significant and positive correlation with it, could be used together or as indirect selection for the character. Only the variables NR and FLL did not present correlation with RL, thus variables SL, FLIH, RDM and SDM presented reduction proportional to the ones seen for RL. Despite the significance in correlation, the values observed for FLIH (64\%) were considerably smaller than variables SL, RDM and SDM, with values of 97, 94 and $95 \%$, respectively. Result suggested that the variable FLIH should not be used for this type of study. Therefore, the variables SL, RDM and SDM could efficiently be used for inferences relative to the tolerance level of plants evaluated in hydroponic systems.

Table 2 - Pearson's correlation estimates among the seven analyzed variables in the selection of organic acid levels for oat tolerance studies under hydroponic system.

\begin{tabular}{|c|c|c|c|c|c|c|c|}
\hline Variables & RL & SL & NR & FLL & FLIH & RDM & SDM \\
\hline $\mathrm{RL}^{1}$ & & $0.971 *$ & $0.230^{\mathrm{ns}}$ & $0.476^{\mathrm{ns}}$ & $0.639^{*}$ & $0.939^{*}$ & $0.950 *$ \\
\hline SL & & & $0.158^{\mathrm{ns}}$ & $0.567 *$ & $0.707 *$ & $0.921^{*}$ & $0.929 *$ \\
\hline NR & & & & $-0.289^{\mathrm{ns}}$ & $0.341^{\mathrm{ns}}$ & $0.294^{\mathrm{ns}}$ & $0.246^{\mathrm{ns}}$ \\
\hline FLL & & & & & $0.502^{\mathrm{ns}}$ & $0.419^{\mathrm{ns}}$ & $0.415^{\mathrm{ns}}$ \\
\hline FLIH & & & & & & $0.600 *$ & $0.575^{*}$ \\
\hline RDM & & & & & & & $0.943 *$ \\
\hline SDM & & & & & & & \\
\hline
\end{tabular}

* Significant at $5 \%$ error probability by the $\mathrm{t}$ test;

${ }^{\mathrm{n}} \mathrm{N}$ Non significant at $5 \%$ error probability by the $\mathrm{t}$ test;

${ }^{1}$ RL: root length; SL: shoot length; NR: number of roots; FLL: length of the first leaf; FLIH: first leaf insertion height; RDM: root dry matter; and SDM: shoot dry matter. 
It should be noted that the methods here presented should be considered as an option in setting up experiments aiming to evaluate oat genotypes for stress caused by the organic acids, and that additional factors would be crucial for conducting an experiment with this objective. The quality of the nutrient solution and the water used, $\mathrm{pH}$ monitoring, temperature and light intensity during the growth of plants and the aseptic conditions of the apparatus are also decisive for such type of experiment.

\section{CONCLUSIONS}

The germination system in the folded germination paper, using small and husked oat seeds at $25^{\circ} \mathrm{C}$ and relative humidity of $100 \%$ for $72 \mathrm{~h}$ enabled high and uniform germination indices for the organic acid tolerance studies for the oat crop under hydroponic systems.

The most indicated concentration range for the organic acid tolerance studies in oat was between 2.3 and $6.2 \mathrm{mM}$ at a ratio of $6: 3: 1$ for acetic, propionic and butyric acids, respectively.

The variable which showed the highest reduction related to organic acid stress was root length, and the variables shoot length, root dry matter and shoot dry matter also presented potential as indicators of organic acid tolerance in oat.

\section{RESUMO}

A ocorrência de condições anaeróbias nos solos hidromórficos favorece o desenvolvimento de microrganismos anaeróbios que produzem substâncias fitotóxicas representadas principalmente pelos ácidos orgânicos. A seleção de constituições genéticas de aveia (Avena sativa L.) promissoras para utilização nestas situações requer avaliações de difícil execução no campo, tornando a utilização de sistemas hidropônicos mais vantajosa. O objetivo deste trabalho foi ajustar uma metodologia para ser utilizada em estudos de tolerância a ácidos orgânicos em aveia através de sistemas hidropônicos. Para tal fim foi determinada uma forma adequada de promover a germinação das sementes de maneira a reduzir os efeitos do estabelecimento inicial das plântulas na hidroponia, uma faixa de concentração ideal para discriminação dos genótipos e as variáveis de maior interesse para avaliação. O sistema de germinação mais eficiente é através de "papel de germinação plissado" com sementes pequenas e descascadas. A faixa de concentração mais adequada para estudos de tolerância a ácidos orgânicos em aveia está entre 2,3 e $6,2 \mathrm{mM}$ e a variável mais indicada é comprimento de raízes.

\section{REFERENCES}

Armstrong, J. and Armstrong, W. (2001), Rice and Phragmites: effects of organic acids on growth, root permeability, and radial oxygen loss to the rhizosphere. American Journal of Botany, 88, 13591370.

Bilinski, J.J. and Foy, C.D. (1987), Differential tolerances of oat cultivars to aluminum in nutrient solutions and in acid soils of plant. Journal of Plant Nutrition, 10, 129-141.

Bohnen, H.; Silva, L.S.; Macedo, V.R.M. and Marcolin, E. (2005), Ácidos orgânicos na solução de um gleissolo sob diferentes sistemas de cultivo com arroz irrigado. Revista Brasileira de Ciência do Solo, 29, 475-480.

Bortolon, L.; Sousa, R.O. and Vahl, L.C. (2002), Crescimento de plântulas de arroz em solução nutritiva submetidas a diferentes doses dos ácidos acético, propiônico e butírico. Abstract presented at I Congresso da Cadeia Produtiva do Arroz / VII RENAPA, 2002, Florianópolis. Santo Antônio de Goiás: Embrapa Arroz e Feijão, p.134.

Camargo, de O.C.E and Oliveira, O.F. (1981), Tolerância de cultivares de trigo a diferentes níveis de alumínio em solução nutritiva e no solo. Bragantia, 49, 21-23.

Camargo, F.A.; Santos, G.A. and Rossielo, R.O.P. (1993), Efeito dos ácidos acético e butírico sobre o crescimento de plântulas de arroz. Pesquisa Agropecuária Brasileira, 28, 1011-1018.

Camargo, F.A.; Zonta, E.; Santos, G.A. and Rossielo, R.O.P. (2001), Aspectos fisiológicos e caracterização de toxidez a ácidos orgânicos voláteis em plantas. Ciência Rural, 31, 523-529.

Coimbra, J.L.M.; Carvalho, F.I.F.; Oliveira, A.C.; Chocorosqui, V.R. and Guidolin, A.F. (2004), Criação de variabilidade genética no caráter ciclo vegetativo em aveia: hibridação artificial x mutação induzida. Revista Brasileira de Agrociência,10, 159166.

Cruz, R.P. (2001), Bases genéticas da tolerância ao frio em arroz (O. sativa L.). Dr. Thesis, Departamento de Plantas de Lavoura, Universidade Federal do Rio grande do Sul, Porto Alegre, Brasil.

Duncan, R.R. and Baligar, V.C. (1990), Genetics, breeding, and physiological mechanisms of nutrient uptake and use efficiency: an overview. In-Crops as 
Enhancers of Nutrient Use, Ed. Baligar, V.C. and Duncan, R.R. San Diego: Academic Press, pp.3-35.

Floss, E.L. (1992), Avaliação da toxicidade do alumínio em genótipos de aveia. Dr. Thesis, Escola Superior de Agricultura "Luiz de Queiroz", Universidade de São Paulo, São Paulo, Brasil.

Freitas, F.A. (2003), Dissimilaridade genética em arroz (Oryza sativa L.) quanto a toxicidade ao alumínio. Ms.C. Thesis, Faculdade de Agronomia "Eliseu Maciel", Universidade Federal de Pelotas, Pelotas, Brasil.

Harper, S.H.T. and Lynch, J.M. (1982), The role of water-soluble components in phytotoxicity from decomposing straw. Plant and Soil, 65, 11-17.

Jones, H.G. and Jones, M.B. (1992), Introduction: Some terminology and commom mechanisms. InPlants Under Stress, Ed. Jones, H.G.; Flowers, T.J. and Jones, M.B. Cambridge University: Academic Press, pp.1-10.

McCullagh, P. and Nelder, J.A. (1989), Generalized Linear Models, Second Edition. London: Chapman and Hall. 268p.

Nelder, J.A. and Wedderburn, R.W.M. (1972), Generalized Linear Models, Journal of the Royal Statistical Society, 135, 370 -384.

Pinto, L.F.E.; Laus, J.A. and Pauletto, E.A. (2004), Solos de várzea no sul do Brasil. In-Arroz irrigado no sul do Brasil, Ed. Gomes, A.S. and Magalhães Jr, A.M. Brasília: Embrapa-Informação Tecnológica, pp.75-95.

Ponnamperuma, F.M. (1972), The chemistry of submerged soils. Advances in Agronomy, 24, 29-96.
Porto, M.P. (1997), Método de seleção de plantas de milho para tolerância ao encharcamento do solo. Pesquisa Agropecuária Gaúcha, 3, 187-190.

Rao, D.N. and Mikkelsen, D.S. (1977a), Effect of acetic, propionic, and butyric acids on young rice seedlings growth. Agronomy Journal, 69, 923-928.

Rao, D.N. and Mikkelsen, D.S. (1977b), Effect of acetic, propionic, and butyric acids on rice seedlings growth. and nutrition. Plant and Soil, 47, 323-334.

Sousa, R.O. and Bortolon, L. (2002), Crescimento radicular e da parte aérea do arroz (Oryza sativa L.) e absorção de nutrientes em solução nutritiva com diferentes concentrações de ácido acético. Revista Brasileira de Agrociência ,8, 231-235.

Sousa, R.O. (2001), Oxirredução em solos alagados afetada por resíduos vegetais. Dr. Thesis, Departamento de Solos, Universidade Federal do Rio Grande do Sul, Porto Alegre, Brasil.

Statistical Analysis System. (2002), SAS: Statistical Analysis System-Getting Started with the SAS Learning Edition. Cary, NC: SAS Institute inc. 86p.

Takenaga, H. (1995), Nutrient absorption in relation to environmental factors. In-Science of the rice plant: physiology, Ed. Matsuo, T.; Kumazawa, K. and Ishii, R. Tokyo: Nosan Gyoson Bunka Kyokai, pp.278-294. Wright, R.J. (1989), Soil aluminum toxicity and plant growth. Communications in Soil Science and Plant Analysis, 20, 1479-1497. 